\title{
Dose to Curie Determination for Containers with Measurable Cs-137
}

Prepared for the U.S. Department of Energy

Assistant Secretary for Environmental Management

Contractor for the U.S. Department of Energy

under Contract DE-AC06-08RL14788

CH2MHILL

Plateau Remediation Company

P.O. Box 1600

Richland, Washington 99352 
CHPRC-00922

Revision 0

\section{Dose to Curie Determination for Containers with Measurable Cs-137}

L. A. Rathbun

CH2M HILL Plateau Remediation Company

J. D. Anderson

Project Enhancement Corporation

Date Published

December 2010

Prepared for the U.S. Department of Energy

Assistant Secretary for Environmental Management

Contractor for the U.S. Department of Energy

under Contract DE-AC06-08RL14788

\section{CH2MHILL}

Plateau Remediation Company

P.O. Box 1600

Richland, Washington

R. D. Aardel $\frac{10 / 03 / 2010}{\text { Date }}$ 
CHPRC-00922

Revision 0

TRADEMARK DISCLAIMER

Reference herein to any specific commercial product, process,

or service by trade name, trademark, manufacturer, or

otherwise, does not necessarily constitute or imply its

endorsement, recommendation, or favoring by the United

States Government or any agency thereof or its contractors or subcontractors.

This report has been reproduced from the best available copy.

Printed in the United States of America 


\section{Contents}

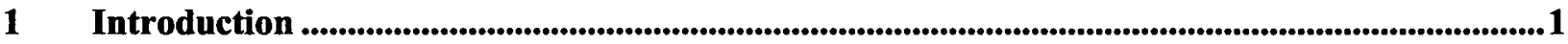

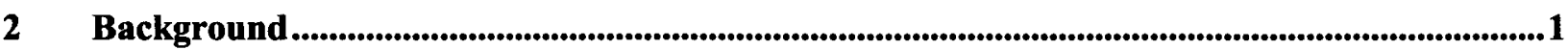

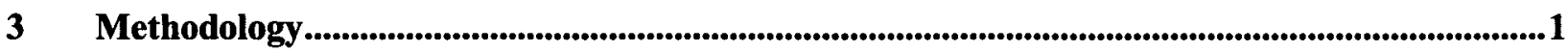

3.1 Procedure for Categorizing and Inventorying Waste in Standard Containers.........................2

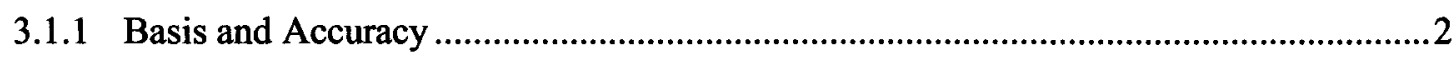

3.1.2 Procedure for the Nonautomated Worksheet Process ................................................ 3

3.1.3 Procedure for the Automated Worksheet Process ...........................................................4

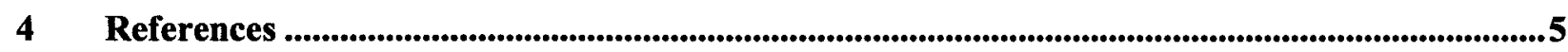

\section{Appendices}

A A-1 Nonautomated Worksheet for 55-Gallon Drum with 1/2-Inch Rubber Lining ............... A-1-i

A-2 Automated Worksheet for 55-Gallon Drum with 1/2-Inch Rubber Lining ...................... A-2-i

A-3 Calculations Supporting the Automated Worksheet for 55-Gallon Drum with 1/2-Inch Rubber Lining..................................................................................... A-3-i

B B-1 Nonautomated Worksheet for 85-Gallon Drum ............................................................. B-1-i

B-2 Automated Worksheet for 85-Gallon Drum .................................................................... B-2-i

B-3 Calculations Supporting the Automated Workseet for 85-Gallon Drum........................ B-3-i

C C-1 Nonautomated Worksheet for 4 by 7 by 3-Foot Box ................................................... C-1-i

C-2 Automated Worksheet for 4 by 7 by 3-Foot Box.................................................................. C-2-i

C-3 Calculations Supporting the Automated Worksheet for 4 by 7 by 3-Foot Box .............. C-3-i

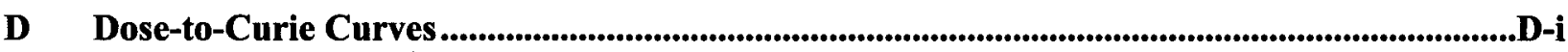

\section{Tables}

Table 1. Calculation Worksheet 
CHPRC-00922, REV.0 
CHPRC-00922, REV.0

\section{Terms}

$\mathrm{Ci}$

CP

cpm

$\mathrm{mR} / \mathrm{hr}$

mrem

NGR

PUREX

RH

$\mathrm{R} / \mathrm{hr}$

TRU

TSD curie

Eberline RO-3B, also known as the Hanford "Cutie Pie"

counts per minute

milliRoentgens per hour

millirem

Next Generation Retrieval

plutonium-uranium extraction

remote-handled

Roentgens per hour

transuranic

treatment, storage, and disposal 
CHPRC-00922, REV.0 


\section{Introduction}

The Next Generation Retrieval (NGR) project will retrieve suspect transuranic (TRU) waste containers from Trenches 17 and 27 in the 218-E-12B (12B) burial ground. The trenches were in operation from May 1970 through October 1972. A portion of the retrieved containers that will require shipment to and acceptance at a treatment, storage, and disposal (TSD) facility and the containers will be either remote-handled ( $\mathrm{RH})$ and/or contact-handled $(\mathrm{CH})$. The method discussed in this document will be used for the $\mathrm{RH}$ and some of the $\mathrm{CH}$ containers to determine the radionuclide inventory.

Waste disposition (shipment and TSD acceptance) requires that the radioactive content be characterized for each container. Source-term estimates using high resolution, shielded, gamma-ray scan assay techniques cannot be performed on a number of $\mathrm{RH}$ and other containers with high dose rates from ${ }^{137} \mathrm{Cs}-{ }^{137 \mathrm{~m}} \mathrm{Ba}$. This document provides the method to quantify the radioactive inventory of fission product gamma emitters within the containers based on the surface dose rate measurements taken in the field with hand-held survey instruments.

\section{Background}

A method to estimate container source terms using field survey instruments was developed and published in Basis for Dose Rate to Curie Assay Method (WHC-SD-WM-RPT-267) (henceforth, the Basis Report). The method is valid for waste with a typical Hanford isotopic distribution and a gamma-emission spectrum dominated by the decay combination from ${ }^{137} \mathrm{Cs}-{ }^{137 m} \mathrm{Ba}$.

Burial ground 218-E-12B includes waste from the Plutonium-Uranium Extraction (PUREX) Plant D-5 hot cell. The D-5 hot cell was used to monitor the amount of plutonium (Pu), neptunium (Np), and uranium $(U)$ in the solution that was used as feed material at the PUREX plant. The D-5 hot cell generated the RH waste that was placed into 55-gallon drums and sent to 218-E-12B for disposal (Acceptable Knowledge Evaluation and Summary Report for TRU Mixed-Debris Waste 218-E-12B, Trenches 17 and 27, WMP-31661). Drums were typically lined with rubber matting to minimize the number of photons generated as beta particles encountered the side of the steel drum. This waste is now approximately 39 years old (based on 1971 as an average), which means that the short-lived radionuclides have decayed over time and the major remaining gamma-emission contributor is the ${ }^{137} \mathrm{Cs}-{ }^{137 \mathrm{~m}} \mathrm{Ba}$ pair. Any contribution to the measured gamma spectrum from in-growth of ${ }^{241} \mathrm{Am}$ will conservatively overestimate the source-term values produced using this method.

\section{Methodology}

The following describes the approach that will be used to characterize the NGR RH waste and to assign an estimated fission product curie $(\mathrm{Ci})$ value to the $\mathrm{RH}$ rubber lined drum, 85-gallon drum, and metal box. This method can also be applied to drums without rubber liners, because the absence of a liner will provide readings on field survey instruments that will yield a higher (more conservative) source-term estimate.

The dose-to-curie curves developed for the six-point surveys in the Basis Report (WHC-SD-WM-RPT-267), were found to be applicable to the NGR containers to be retrieved. The centrally located point source and distributed source curves were evaluated and were shown to yield similar results for the expected waste weights.

Void space and/or elemental composition of the waste will not have a significant impact on the curies of

${ }^{137} \mathrm{Cs}$ that are determined from surface dose rates, as noted in the Basis Report (WHC-SD-WM-RPT-267). 
Appendices A-2, B-2, and C-2 provide examples of the dose-to-curie automated worksheets. The actual worksheets establish ${ }^{137} \mathrm{Cs}$ and other fission product radionuclide activity for the $\mathrm{RH}$ containers based on a six-point survey (dose-rate measurements). The methodology is similar for each type of RH container being evaluated. Three worksheets provide calculations for RH containers: (1) a 55 gal (208 liter [L]) drum with or without a rubber liner, (2) an 85 gal (321 L) drum, and (3) a $4 \mathrm{ft}$ by $7 \mathrm{ft}$ by $3 \mathrm{ft}(1.2 \mathrm{~m}$ by 2.1 $\mathrm{m}$ by $0.9 \mathrm{~m}$ ) metal box.

The values from the curves in Appendix $\mathrm{D}$ are captured in the dose-to-curie columns shown in Appendices A-1, B-1 and C-1. The automated worksheets use these values to calculate the activity of ${ }^{137} \mathrm{Cs}$. The activities of other beta-gamma-emitting nuclides, based on the PUREX D-5 hot cell source term were decayed to present values and are ratioed from the ${ }^{137} \mathrm{Cs}$ activity. The curie values derived from the curves in Appendix D are based on similar containers described in the Basis Report (WHC-SD-WM-RPT-267). The points on the curves shown in Appendix A-1 are 15 percent higher than those for the 55-gallon drum shown in the Basis Report (WHC-SD-WM-RPT-267) to account for the rubber liner. The points on the curves shown in Appendix B-1 for the 85-gallon drum are 54.5 percent higher than those for the 55-gallon drum shown in the Basis Report (WHC-SD-WM-RPT-267) to account for the difference in volume. The points on the curves shown in Appendix C-1 for the $4 \mathrm{ft}$ by $7 \mathrm{ft}$ by $3 \mathrm{ft}$ $(1.2 \mathrm{~m}$ by $2.1 \mathrm{~m}$ by $0.91 \mathrm{~m})$ box are 44.4 percent higher than those for the $3 \mathrm{ft}$ by $3 \mathrm{ft}$ by $6 \mathrm{ft}(0.91 \mathrm{~m}$ by $0.91 \mathrm{~m}$ by $1.83 \mathrm{~m}$ ) box shown in the Basis Report (WHC-SD-WM-RPT-267) to account for the difference in volume.

\subsection{Procedure for Categorizing and Inventorying Waste in Standard Containers}

This procedure is based on the calculations that relate the inventory to the surface dose rate (WHC-SD-WM-RPT-267).

\subsubsection{Basis and Accuracy}

The calculations examined the parameters that affect the surface dose rate to radioisotope inventory relationship (WHC-SD-WM-RPT-267). This leads to the following conclusions and requirements:

1. The surface dose rate is relatively insensitive to the composition of the waste material; therefore, a single (upper limit composition) curve yields a mildly conservative inventory. This conservative bias accommodates some of the uncertainty associated with the method.

2. For the waste streams evaluated, the surface dose rate is dominated by ${ }^{137} \mathrm{Cs}$. By assuming the surface dose rate defines the inventory of ${ }^{137} \mathrm{Cs}$, a conservative bias is introduced into the overall inventory determination and categorization. The greater the surface dose contribution of isotopes other than ${ }^{137} \mathrm{Cs}$, the greater the bias. These conservative biases generally accommodate the uncertainty of the method.

3. This procedure is only applicable if ${ }^{137} \mathrm{Cs}$ is known to exist in the waste in significant amounts (e.g., ${ }^{137} \mathrm{Cs}$ greater than 20 percent of the total non-TRU nuclide activity).

4. This procedure should not be used if the waste is known to contain a sufficient quantity of other dose dominant isotopes, such as ${ }^{60} \mathrm{Co}$ (however, this is not anticipated because the half-life of ${ }^{60} \mathrm{Co}$ is 5.27 years; currently, there are 7.4 half-lives, based on 39 years of storage).

5. Voids, located within otherwise uniformly distributed waste material, will not introduce significant error into the inventory determination.

6. Localized source concentrations, other than those centrally distributed, can be detected by the variation in individual surface dose rate readings from the average. For standard containers, a 
maximum/average ratio greater than 2.5 indicates the source distribution to be significantly heterogeneous.

7. If there is reason to believe the inventory is an approximately centrally located point source or other significantly heterogeneous source, it is always conservative to assume the point source option. Alternately, the container can be analyzed outside of this procedure as a special case. ${ }^{1}$

8. Measured dose rates are to be contact readings made with an Eberline RO-3B (CP) Radiation Survey Instrument. The calculations ${ }^{2}$ assume that the center of the CP detector volume is approximately 2 in. $(5 \mathrm{~cm})$ from the container surface. If an instrument other than a CP is used, care must be taken to ensure that the center of that detector volume is $2 \mathrm{in} .(5 \mathrm{~cm})$ from the container surface.

9. The six points where the dose rates should be measured are the geometric centers of each face of the container. For drums, four of the measurements taken should be separated by $90^{\circ}$ around the drum circumference, half-way along the length of the drum.

10. The TRU radionuclides will be determined by neutron assay. ${ }^{3}$

\subsubsection{Procedure for the Nonautomated Worksheet Process}

For those containers that are not referenced in this document, a custom calculation can be developed using this methodology:

1. Enter the curies of each isotope in the waste stream mix in Appendix A-1, Column 2 of the Worksheet.

2. Sum the Ci values in Column 2 (Appendix A-1) and enter the value at the bottom of the Column in the space for $\Sigma$ (sum).

3. Normalize the waste stream mix of Category 1 constituents by dividing the Ci value of each isotope in Column 2 by the sum $\Sigma$ of Column 2 . The sum of Column 3 should be unity.

4. Obtain the six surface dose rate values and enter these in the worksheet, including information concerning the radiation detector (see Section 3.1.1, number 8).

5. Obtain the average surface dose rate by summing the six readings and dividing the sum by six. Subtract the background. Record the corrected average on the worksheet.

Note: Convert the corrected average value reading into units Roentgens per hour $(\mathrm{R} / \mathrm{hr})$ even though they were obtained as counts per minute $(\mathrm{cpm})$, milliRoentgens per hour $(\mathrm{mR} / \mathrm{hr})$, or other.

6. Divide the background corrected maximum of the six individual readings by the background corrected average value and enter this on the worksheet as the maximum/average value.

7. Weigh the waste container and enter this value on the worksheet.

8. Subtract the standard empty container weight from the gross weight obtained in Step 7 and enter this net weight value on the Worksheet.

9. Using the net weight from Step 8, locate the appropriate attached figure for the type of container and determine the $\mathrm{Ci}$ of ${ }^{137} \mathrm{Cs}$ per $\mathrm{R} / \mathrm{hr}$. If the maximum/average value in Step 6 is equal to or less than

\footnotetext{
1 Special case containers will be analyzed separately by a technical specialist.

2 Supporting calculations were performed using the Monte Carlo N-Particle computer code (WHC-SD-WM-RPT-267).

3 RH TRU isotopics will be determined by neutron assay, not gamma assay.
} 
2.5, use the homogeneous (distributed source) curve. If the maximum/average value from Step 6 is greater than 2.5, use the heterogeneous (point source) curve, or subject the container to an alternative assay procedure or a case-by-case assessment.

10. Multiply the $\mathrm{Ci}$ of ${ }^{137} \mathrm{Cs}$ per $\mathrm{R} / \mathrm{hr}$ from Step 9 by the average surface dose rate value (in $\mathrm{R} / \mathrm{hr}$ ) from Step 5. Enter this $\mathrm{Ci}$ value of ${ }^{137} \mathrm{Cs}$ in Column 4 in the ${ }^{137} \mathrm{Cs}$ row of Table 1.

11. Divide the Ci value for ${ }^{137} \mathrm{Cs}$ in Column 4 by the value for ${ }^{137} \mathrm{Cs}$ in Column 3 and enter this value in the space for "factor" at the top of Column 4 . This is the factor for quantifying the Ci inventory of other radioisotopes.

12. Multiply each Ci value in Column 3 by the normalizing "factor" at the top of Column 4 (see Step 11) and enter the resulting value for each isotope in the appropriate row in Column 4.

13. Enter the standard volume of the container on the worksheet.

14. Divide the Ci inventory in each row of Column 4 by the standard container volume from the worksheet to obtain the curies per cubic meter $\left(\mathrm{Ci} / \mathrm{m}^{3}\right)$ for each radioisotope that has a known Category 1 limit.

15. Divide the Ci concentration of each isotope in Column 5 by its Category 1 limit listed in Column 6 and enter the resulting value in Column 7 as the fractional contribution of the isotope.

Note: Be sure the decimal point for each fractional contribution is correctly taken into account.

\subsubsection{Procedure for the Automated Worksheet Process}

The automated worksheet process can be used when the required fields are input. Once the calculations are completed in the field, the automated worksheet can be completed and the data input into the Solid Waste Information and Tracking System.

For those containers that are not referenced in this document, a custom calculation can be developed using the methodology in Section 3.1.2 above:

1. Record the container number and the container volume using Appendix A-2, the Automated Worksheet.

Table 1, Calculation Worksheet, provides an example of the isotopic data that will be provided from field measurements. Note: The isotopic data for the TRU radionuclides will be determined by neutron assay.

2. Obtain and record the six surface dose rate values and the background dose rate (from field measurements) and record the data on A-2 (Automated Worksheet), and Table 1. Calculation Worksheet

\begin{tabular}{cc}
\hline ISOTOPE & $\begin{array}{c}\text { Category } \mathbf{1} \text { Limit } \\
\mathbf{C i} / \mathbf{m}^{3}\end{array}$ \\
\hline${ }^{90} \mathrm{Sr}$ & $4.3 \mathrm{E}-3$ \\
${ }^{99} \mathrm{Tc}$ & $5.6 \mathrm{E}-3$ \\
${ }^{137} \mathrm{Cs}$ & $6.3 \mathrm{E}-3$ \\
${ }^{154} \mathrm{Eu}$ & $8.3 \mathrm{E}-1$ \\
\hline
\end{tabular}

$\mathrm{Ci} / \mathrm{m}^{3}=$ curies per cubic meter include the radiation detector information. Provide the date of the measurements.

3. Weigh the waste container and enter this value and the tare weight value on the Worksheet.

4. Input the required data into the A-2 Automated Worksheet.

5. Print out the results from the A-2 Automated Worksheet and attach it to the Field Form Worksheet. Check the Worksheet for correctness, then print, sign, and date the Worksheet. 
The following Appendices have been prepared to implement the Ci characterization of the waste:

- A-1 - Nonautomated Worksheet for 55-Gallon Drum with 1/2-Inch Rubber Lining

- A-2 - Automated Worksheet for 55-Gallon Drum with $1 / 2$-Inch Rubber Lining

- A-3 - Calculations Supporting the Automated Worksheet for 55-Gallon Drum with 1/2-Inch Rubber Lining

- B-1 - Nonautomated Worksheet for 85-Gallon Drum

- B-2 - Automated Worksheet for 85-Gallon Drum

- B-3 - Calculations Supporting the Automated Worksheet for 85-Gallon Drum

- C-1 - Nonautomated Worksheet for 4 by 7 by 3-Foot Box

- C-2 - Automated Worksheet for 4 by 7 by 3-Foot Box

- C-3 - Calculations Supporting the Automated Worksheet for 4 by 7 by 3-Foot Box D - Dose-to-Curie Curves

Note: Appendices A-2, B-2, and C-2 automate the process described in Sections 3.1.2 and 3.1.3 and Appendices A-3, B-3, and C-3 provide the reproducible calculations that support the automated worksheets.

\section{References}

WHC-SD-WM-RPT-267, 1996, Basis for Dose Rate to Curie Assay Method, Rev. 0, Westinghouse Hanford Company, Richland, Washington.

WMP-31661, 2007, Acceptable Knowledge Evaluation and Summary Report for TRU Mixed-Debris Waste 218-E-12B, Trenches 17 and 27, Rev. 1, Fluor Hanford, Inc., Richland, Washington. 
CHPRC-00922, REV.0 
CHPRC-00922, REV. 0

\section{Appendix A-1}

Nonautomated Worksheet for 55-Gallon Drum with $1 / 2-$ Inch Rubber Lining 
CHPRC-00922, REV. 0

A-1-ii 


\section{APPENDIX A-1}

\section{Nonautomated Worksheet for 55-Gallon Drum with 1/2-Inch Rubber Lining Dose Rate to Curie Content}

Instrument Calib or Cert

\begin{tabular}{|c|c|c|}
\hline \multicolumn{3}{|c|}{ Surface Dose Rates } \\
\hline & \multicolumn{2}{|l|}{ Dose rate $(\mathrm{mR} / \mathrm{hr})$} \\
\hline Side 1 & 200 & \\
\hline Side 2 & 205 & \\
\hline Side 3 & 210 & \\
\hline Side 4 & 200 & \\
\hline Top & 195 & \\
\hline Bottom & 185 & \\
\hline Average & 199.1666667 & \\
\hline \multicolumn{2}{|c|}{ Backround Radiation: } & 0.5 \\
\hline \multicolumn{2}{|c|}{ Average - Backround: } & 198.666667 \\
\hline \multirow{2}{*}{\multicolumn{2}{|c|}{$\begin{array}{r}\text { Maximum Dose Rate: } \\
\text { Maximum/Average: }\end{array}$}} & 210 \\
\hline & & 1.05439331 \\
\hline \multicolumn{2}{|c|}{ Dose Rate to Activity Curve: } & Distributed \\
\hline
\end{tabular}

\begin{tabular}{|l|r|}
\hline \multicolumn{2}{|c|}{ Container Information } \\
\hline Net Weight $\geq 0$ and $<\mathbf{2 2 6}$ to 1 decimal place. \\
Container Number \\
Volume $\left(\mathrm{m}^{3}\right)$ \\
Empty Weight $(\mathrm{kg})$ \\
Gross Weight $(\mathrm{kg})$ & \\
\cline { 2 - 2 } Net Weight $(\mathrm{kg})$ & 126.9 \\
\cline { 2 - 2 } & $\mathbf{9 9 . 9}$ \\
\hline
\end{tabular}

\begin{tabular}{|r|c|c|}
\hline \multicolumn{3}{|c|}{ Ci Factor for Drum Wt. } \\
\hline & \multicolumn{1}{|c|}{ Cs-137 Curies per R/hr } \\
Weight (kg) & Point & Distributed \\
\hline 99.9 & 0.8406213 & 0.73119875 \\
\hline
\end{tabular}

\begin{tabular}{|l|r|r|r|r|}
\hline \multicolumn{5}{|c|}{ Isotope Concentration } \\
\hline \multicolumn{1}{|c|}{ Isotope } & Point & Distributed & \multicolumn{2}{c|}{$\begin{array}{c}\text { Distribution (\%) } \\
\text { Point }\end{array}$} \\
\hline Cs-137 & 0.167003 & 0.145265 & $28.82 \%$ & $28.82 \%$ \\
\hline Ba-137m & 0.157868 & 0.137319 & $27.25 \%$ & $27.25 \%$ \\
\hline Sr-90 & 0.127090 & 0.110547 & $21.93 \%$ & $21.93 \%$ \\
\hline Y-90 & 0.127090 & 0.110547 & $21.93 \%$ & $21.93 \%$ \\
\hline Eu-154 & 0.000379 & 0.000330 & $0.07 \%$ & $0.07 \%$ \\
\hline Tc-99 & 0.000057 & 0.000049 & $0.01 \%$ & $0.01 \%$ \\
\hline Pd-107 & 0.000000 & 0.000000 & $0.00 \%$ & $0.00 \%$ \\
\hline Cs-134 & 0.000000 & 0.000000 & $0.00 \%$ & $0.00 \%$ \\
\hline Pm-147 & 0.000041 & 0.000036 & $0.01 \%$ & $0.01 \%$ \\
\hline Eu-155 & 0.000022 & 0.000019 & $0.00 \%$ & $0.00 \%$ \\
\hline \multicolumn{5}{|c|}{} \\
\hline Sum & 0.579430 & 0.504006 & $100 \%$ & $100 \%$ \\
\hline
\end{tabular}


CHPRC-00922, REV. 0

A-1-2 
CHPRC-00922, REV. 0

Appendix A-2

Automated Worksheet for 55-Gallon Drum with $1 / 2-$ Inch Rubber Lining 
CHPRC-00922, REV. 0 


\section{APPENDIX A-2}

\section{Automated Worksheet for 55 Gallon Drum with 1/2-Inch Rubber Lining Dose Rate to Curie Content}

Instrument

\begin{tabular}{|l|l|}
\hline \multicolumn{2}{|c|}{ Surface Dose Rates } \\
\hline & Dose rate (mR/hr) \\
\hline Side 1 & \\
\hline Side 2 & \\
\hline Side 3 & \\
\hline Side 4 & \\
\hline Top & \\
\hline Bottom & \\
\hline Dose Rate to Activity Curve: & \\
\hline \multicolumn{2}{|r|}{ Backround Radiation: } \\
Average - Backround: \\
Maximum Dose Rate: \\
Maximum/Average: \\
Dose Rate to Activity Curve: \\
\hline
\end{tabular}

Prepared by:

Print Name

Attachments:
Calib or Cert

\begin{tabular}{|l|}
\hline \multicolumn{2}{|c|}{ Container| Information } \\
\hline \multicolumn{2}{|c|}{ Net Weight $\geq 0$ and $<\mathbf{2 2 6}$ to 1 decimal place. } \\
Container Number \\
Volume $\left(\mathrm{m}^{3}\right)$ \\
Empty Weight $(\mathrm{kg})$ \\
Gross Weight $(\mathrm{kg})$ \\
Net Weight $(\mathrm{kg})$
\end{tabular}

Signature

Date: 
CHPRC-00922, REV. 0

A-2-2 


\section{Appendix A-3}

Calculations Supporting the Automated Worksheet for 55-Gallon Drum with $1 / 2-$ Inch Rubber Lining 
CHPRC-00922, REV. 0

A-3-ii 


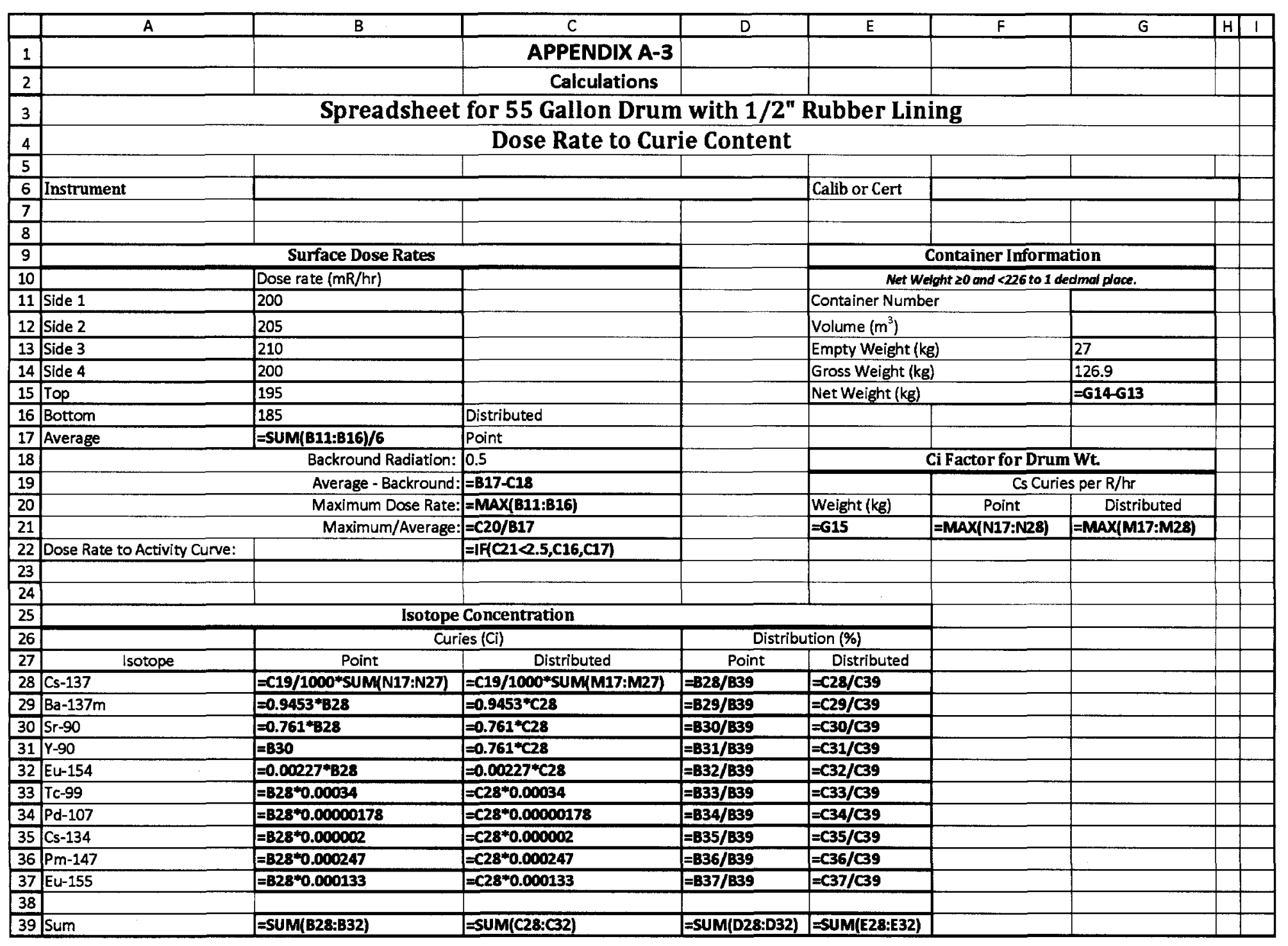




\begin{tabular}{|c|c|c|c|c|c|}
\hline & $\mathrm{J}$ & $\mathrm{K}$ & $L$ & $M$ & $\bar{N}$ \\
\hline \multicolumn{6}{|l|}{1} \\
\hline 2 & & & Weight & distrib & point \\
\hline 3 & & & 0 & 0.5049 & 0.4928 \\
\hline 4 & & & 10 & 0.5192 & 0.53306 \\
\hline 5 & & & 27.5 & 0.548515 & 0.572605 \\
\hline 6 & & & 45 & 0.57783 & 0.61215 \\
\hline 7 & & & 67.5 & 0.62502 & 0.68288 \\
\hline 8 & & & 90 & 0.67221 & 0.75361 \\
\hline 9 & & & 112.5 & 0.726605 & 0.854535 \\
\hline 10 & & & 135 & 0.781 & 0.95546 \\
\hline 11 & & & 157.5 & 0.84106 & 1.1088 \\
\hline 12 & & & 180 & 0.90112 & 1.26203 \\
\hline 13 & & & 203 & 0.96976 & 1.49017 \\
\hline $14 \mid$ & & & 226 & 1.0384 & 1.71831 \\
\hline \multicolumn{6}{|l|}{15} \\
\hline 16 & & & Weight & distrib & point \\
\hline 17 & & & 0 & $=\mid F(A N D(0<G 15, G 15<10), A V E R A G E(M 3: M 4), 0)$ & $=I F(A N D(0<G 15, G 15<10), A V E R A G E(N 3: N 4), 0)$ \\
\hline 18 & & & 10 & $=$ IF(AND(9.9<G15,G15<27.5),AVERAGE(M4:M5), 0$)$ & $=$ IF(AND(9.9<G15,G15<27.5),AVERAGE(N4:N5),0) \\
\hline 19 & & & 27.5 & $=$ IF(AND $(27.4<G 15, G 15<45)$, AVERAGE(M5:M6),0) & $=$ IF(AND $(27.4<G 15, G 15<45)$, AVERAGE(N5:N6),0) \\
\hline 20 & & & 45 & $=$ IF(AND(44.9<G15,G15<67.5),AVERAGE(M6:M7),0) & $=I F(A N D(44.9<G 15, G 15<67.5), A V E R A G E(N 6: N 7), 0)$ \\
\hline 21 & & & 67.5 & $=$ IF(AND $(67.4<G 15, G 15<90)$, AVERAGE(M7:M8), 0) & $=I F(A N D(67.4<G 15, G 15<90)$, AVERAGE(N7:N8),0) \\
\hline 22 & & & 90 & $=$ IF(AND $(89.9<G 15, G 15<112.5)$, AVERAGE(M8:M9),0) & $=$ IF $($ AND $(89.9<G 15, G 15<112.5)$, AVERAGE(N8:N9), 0$)$ \\
\hline 23 & & & 112.5 & $=\mid \mathrm{F}(\mathrm{AND}(112.4<\mathrm{G} 15, \mathrm{G} 15<135), \mathrm{AVERAGE}(\mathrm{M} 9: \mathrm{M} 10), 0)$ & $=$ IF(AND(112,4<G15,G15<135),AVERAGE(N9:N10),0) \\
\hline 24 & & & 135 & $=\mid \mathrm{F}(\mathrm{AND}(134.9<\mathrm{G} 15, \mathrm{G} 15<157.5)$,AVERAGE(M10:M11),0) & $=\mid F(A N D(134.9<G 15, G 15<157.5), A V E R A G E(N 10: N 11), 0)$ \\
\hline 25 & & & 157.5 & $=\mid \mathrm{F}(\mathrm{AND}(157.4<G 15, \mathrm{G} 15<180)$, AVERAGE(M11:M12),0) & $=I F(A N D(157.4<G 15, G 15<180), A V E R A G E(N 11: N 12), 0)$ \\
\hline 26 & & & 180 & $=\mid \mathrm{F}(\mathrm{AND}(179.9<\mathrm{G} 15, \mathrm{G} 15<203), \mathrm{AVERAGE}(\mathrm{M} 12 \mathrm{M} 13), 0)$ & $=1$ F(AND(179.9<G15,G15<203),AVERAGE(N12:N13),0) \\
\hline 27 & & & 203 & $=I F(A N D(202.9<G 15, G 15<226), A V E R A G E(M 13: M 14), 0)$ & $=$ IF(AND(202.9<G15,G15<226), AVERAGE(N13:N14),0) \\
\hline 28 & & & 226 & & \\
\hline \multicolumn{6}{|l|}{29} \\
\hline \multicolumn{6}{|l|}{30} \\
\hline \multicolumn{6}{|l|}{31} \\
\hline \multicolumn{6}{|l|}{32} \\
\hline \multicolumn{6}{|l|}{33} \\
\hline \multicolumn{6}{|l|}{34} \\
\hline \multicolumn{6}{|l|}{35} \\
\hline \multicolumn{6}{|l|}{36} \\
\hline \multicolumn{6}{|l|}{37} \\
\hline \multicolumn{6}{|l|}{38} \\
\hline 39 & & & & & \\
\hline
\end{tabular}


CHPRC-00922, REV. 0

Appendix B-1

Nonautomated Worksheet for 85-Gallon Drum 
CHPRC-00922, REV. 0

B-1-ii 


\section{APPENDIX B-1}

\section{Nonautomated Worksheet for 85-Gallon Drum Dose Rate to Curie Content}

Instrument

\begin{tabular}{|c|c|c|}
\hline \multicolumn{3}{|c|}{ Surface Dose Rates } \\
\hline & \multicolumn{2}{|c|}{ Dose rate $(\mathrm{mR} / \mathrm{hr})$} \\
\hline Side 1 & 200 & \\
\hline Side 2 & 205 & \\
\hline Side 3 & 210 & \\
\hline Side 4 & 200 & \\
\hline Top & 195 & \\
\hline Bottom & 185 & \\
\hline Average & 199.166667 & \\
\hline \multicolumn{2}{|c|}{ Backround Radiation: } & 0.5 \\
\hline \multicolumn{2}{|c|}{ Average - Backround: } & 198.666667 \\
\hline \multicolumn{2}{|c|}{ Maximum Dose Rate: } & 210 \\
\hline \multicolumn{2}{|c|}{ Maximum/Average: } & 1.05439331 \\
\hline \multicolumn{2}{|c|}{ Dose Rate to Activity Curve: } & Distributed \\
\hline
\end{tabular}

Calib or Cert

\begin{tabular}{|l|r|}
\hline \multicolumn{2}{|c|}{ Container Information } \\
\hline Net Weight $\geq 0$ and $<226$ to 1 decimal place. \\
\hline Container Number \\
Volume $\left(\mathrm{m}^{3}\right)$ \\
Empty Weight $(\mathrm{kg})$ \\
\cline { 2 - 2 } Gross Weight $(\mathrm{kg})$ \\
Net Weight $(\mathrm{kg})$ & $\mathbf{3 5}$ \\
\cline { 2 - 2 } & $\mathbf{9 1 . 9}$ \\
\hline
\end{tabular}

\begin{tabular}{|r|c|c|}
\hline \multicolumn{3}{|c|}{ Ci Factor for Drum Wt. } \\
\hline & \multicolumn{2}{|c|}{ Cs-137 Curies per R/hr } \\
Weight (kg) & Point & Distributed \\
\hline 91.9 & 1.689649 & 1.46970949 \\
\hline
\end{tabular}

\begin{tabular}{|c|c|c|c|c|}
\hline \multicolumn{5}{|c|}{ Isotope Concentration } \\
\hline \multirow[b]{2}{*}{ Isotope } & \multicolumn{2}{|c|}{ Curies (Ci) } & \multicolumn{2}{|c|}{ Distribution (\%) } \\
\hline & Point & Distributed & Point & Distributed \\
\hline Cs-137 & 0.335677 & 0.291982 & $28.82 \%$ & $28.82 \%$ \\
\hline Ba-137m & 0.317315 & 0.276011 & $27.25 \%$ & $27.25 \%$ \\
\hline Sr-90 & 0.255450 & 0.222199 & $21.93 \%$ & $21.93 \%$ \\
\hline$Y-90$ & 0.255450 & 0.222199 & $21.93 \%$ & $21.93 \%$ \\
\hline Eu-154 & 0.000762 & 0.000663 & $0.07 \%$ & $0.07 \%$ \\
\hline TC-99 & 0.000114 & 0.000099 & $0.01 \%$ & $0.01 \%$ \\
\hline Pd-107 & 0.000001 & 0.000001 & $0.00 \%$ & $0.00 \%$ \\
\hline Cs-134 & 0.000001 & 0.000001 & $0.00 \%$ & $0.00 \%$ \\
\hline Pm-147 & 0.000083 & 0.000072 & $0.01 \%$ & $0.01 \%$ \\
\hline Eu-155 & 0.000045 & 0.000039 & $0.00 \%$ & $0.00 \%$ \\
\hline Sum & 1.164654 & 1.013053 & $100 \%$ & $100 \%$ \\
\hline
\end{tabular}


CHPRC-00922, REV. 0

B-1-2 
CHPRC-00922, REV. 0

\section{Appendix B-2}

Automated Worksheet for 85-Gallon Drum 
CHPRC-00922, REV. 0

B-2-ii 


\section{APPENDIX B-2}

\section{Automated Worksheet for 85-Gallon Drum Dose Rate to Curie Content}

\begin{tabular}{|c|c|}
\hline \multicolumn{2}{|c|}{ Surface Dose Rates } \\
\hline & Dose rate $(\mathrm{m}$ \\
\hline \multicolumn{2}{|l|}{ Side 1} \\
\hline \multicolumn{2}{|l|}{ Side 2} \\
\hline \multicolumn{2}{|l|}{ Side 3} \\
\hline \multicolumn{2}{|l|}{ Side 4} \\
\hline \multicolumn{2}{|l|}{ Top } \\
\hline \multicolumn{2}{|l|}{ Bottom } \\
\hline \multicolumn{2}{|l|}{ Average } \\
\hline \multicolumn{2}{|c|}{ Backround Radiation: } \\
\hline \multicolumn{2}{|c|}{ Average - Backround: } \\
\hline \multicolumn{2}{|c|}{ Maximum Dose Rate: } \\
\hline \multicolumn{2}{|c|}{ Maximum/Average: } \\
\hline \multicolumn{2}{|c|}{ Dose Rate to Activity Curve: } \\
\hline
\end{tabular}

\begin{tabular}{|c|c|}
\hline Container In & mation \\
\hline Net Weight $\geq 0$ and $<22$ & 1 decimal place. \\
\hline Container Number & \\
\hline Volume $\left(\mathrm{m}^{3}\right)$ & \\
\hline Empty Weight (kg) & \\
\hline Gross Weight (kg) & \\
\hline Net Weight (kg) & \\
\hline
\end{tabular}

Prepared by:

Print Name Signature Date:

Attachments: 
CHPRC-00922, REV. 0

B-2-2 


\section{Appendix B-3}

Calculations Supporting the Automated Worksheet for 85-Gallon Drum 
CHPRC-00922, REV. 0

B-3-ii 


\begin{tabular}{|c|c|c|c|c|c|c|c|c|c|c|}
\hline & A & 8 & c & D & $\mathrm{E}$ & $F$ & G & $\mathrm{HI}$ & $\mathrm{j}$ & $\mathrm{K}$ \\
\hline 1 & & & & APPENDIX B-3 & & & & & & \\
\hline 2 & & & & Calculations & & & & & & \\
\hline 3 & \multicolumn{7}{|c|}{ Spreadsheet for 85 Gallon Drum } & & & \\
\hline 4 & \multicolumn{7}{|c|}{ Dose Rate to Curie Content } & & & \\
\hline \begin{tabular}{|l|l}
5 & 1 \\
\end{tabular} & & & & & & & & & & \\
\hline 6 & Instrument & & & & Calib or Cert & & & & & \\
\hline \begin{tabular}{|l|}
7 \\
\end{tabular} & & & & & & & & & & \\
\hline 8 & & & & & & & & & & \\
\hline \begin{tabular}{|l|l}
9 \\
\end{tabular} & \multicolumn{3}{|c|}{ Surface Dose Rates } & & & \multicolumn{2}{|c|}{ Container Information } & & & \\
\hline 10 & & Dose rate $(\mathrm{mR} / \mathrm{hr})$ & & & \multicolumn{3}{|c|}{ Net Welght 20 and $<226$ to 1 dedimel ploce. } & & & \\
\hline 11 & Side 1 & 200 & & & \multirow{2}{*}{\multicolumn{2}{|c|}{\begin{tabular}{|l} 
Container Number \\
Volume $\left(\mathrm{m}^{3}\right)$
\end{tabular}}} & & & & \\
\hline 12 & Side 2 & 205 & & & & & & & & \\
\hline 13 & Side 3 & 210 & & & \multicolumn{2}{|l|}{$\begin{array}{l}\text { volume }\left(\mathrm{m}^{3}\right) \\
\text { Empty Weight (kg) }\end{array}$} & 35 & & & \\
\hline 14 & Side 4 & 200 & & & \multicolumn{2}{|l|}{ Gross Weight (kg) } & 126.9 & & & \\
\hline 15 & Top & 195 & & & \multicolumn{2}{|l|}{ Net Weight (kg) } & $=614-613$ & & & \\
\hline 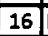 & Bottom & 185 & Distributed & & & & & & & \\
\hline 17 & Average & $=$ SUM(B11:B16)/6 & Point & & & \multirow{2}{*}{\multicolumn{2}{|c|}{ Ci Factor for Drum Wt. }} & & & \\
\hline 18 & & Backround Radiation: & 0.5 & & & & & & & \\
\hline 19 & & Average - Backround: & $=817-C 18$ & & & \multicolumn{2}{|c|}{ Cs Curies per $\mathrm{R} / \mathrm{hr}$} & & & \\
\hline 20 & & Maximum Dose Rate: & $=\operatorname{MaX}(B 11: B 16)$ & & Weight (kg) & Point & Distributed & & & \\
\hline 21 & & Maximum/Average: & $x$ C20/B17 & & $=615$ & $=\operatorname{Max}(\mathrm{N} 17: \mathrm{N} 28)$ & $=\operatorname{Max}(M 17: M 28)$ & & & \\
\hline 22 & Dose Rate to Activity Curve: & & $=I F(21<2.5,(16,(17)$ & & & & & & & \\
\hline \multicolumn{11}{|l|}{23} \\
\hline \begin{tabular}{|l|l|}
24 & -1 \\
\end{tabular} & & & & & & & & & & \\
\hline 25 & \multicolumn{9}{|c|}{ Isotope Concentration } & \\
\hline 26 & & \multicolumn{2}{|c|}{ Curies $(\mathrm{Ci})$} & \multicolumn{2}{|c|}{ Distribution $\left(\%_{0}\right)$} & & & & & \\
\hline 27 & Isotope & Point & Distributed & Point & Distributed & & & & & \\
\hline 28 & Cs-137 & $=C 19 / 1000 *$ SUM(N17:N27) & $=$ C19/1000*SUM(M17:1 & $=B 28 / B 39$ & $=C 28 / C 39$ & & & & & \\
\hline 29 & Ba-137m & $=0.9453 * 828$ & $=0.9453^{*} \mathrm{C} 28$ & $=B 29 / B 39$ & $=C 29 / C 39$ & & & & & \\
\hline 30 & $5 r-90$ & $=0.761 * 828$ & $=0.761^{*} \mathrm{C} 28$ & $=B 30 / B 39$ & $=C 30 / C 39$ & & & & & \\
\hline \begin{tabular}{|l|l}
31 \\
\end{tabular} & Y-90 & $=\mathbf{B 3 0}$ & $=0.761^{*} \mathrm{C} 28$ & $=$ =B31/B39 & $=C 31 / C 39$ & & & & & \\
\hline 32 & Eu-154 & $=0.00227^{*} B 28$ & $-0.00227^{*} \mathrm{C} 28$ & $=832 / 839$ & $=-632 / \mathrm{C} 39$ & & & & & \\
\hline 33 & Te-99 & $=828^{*} 0.00034$ & $=C 28^{*} 0.000034$ & $=B 33 / B 39$ & $=C 33 / C 39$ & & & & & \\
\hline 34 & Pd-107 & $=828 * 0.00000178$ & $=C 28^{*} 0.000000178$ & $=B 34 /$ B39 & $=-634 / C 39$ & & & & & \\
\hline 35 & Cs-134 & $=828^{*} 0.000002$ & $=c 28^{*} 0.000002$ & $=B 35 / B 39$ & $=C 35 / C 39$ & & & & & \\
\hline 36 & Pm-147 & $=828^{*} 0.000247$ & $=C 28^{*} 0.000247$ & $=B 36 / B 39$ & $=c 36 / C 39$ & & & & & \\
\hline 37 & Eu-155 & $=B 28 * 0.000133$ & $=C 28^{*} 0.000133$ & $=B 37 / B 39$ & $-C 37 / C 39$ & & & & & \\
\hline 38 & & & & & & & & & & \\
\hline \begin{tabular}{|l|}
39 \\
\end{tabular} & Sum & $=S U M(B 28 ; B 32)$ & $=$ SUM(C28:C32) & $=$ SUM(D28:D32) & $=$ SUM(E28:E32) & & & & & \\
\hline
\end{tabular}




\begin{tabular}{|c|c|c|c|}
\hline & $L$ & M & $\mathrm{N}$ \\
\hline \multicolumn{4}{|l|}{1} \\
\hline 2 & Weight & distrib & point \\
\hline 3 & 0 & 0.62424 & 0.60928 \\
\hline 4 & 10 & 0.64192 & 0.659056 \\
\hline 5 & 27.5 & 0.678164 & 0.707948 \\
\hline 6 & 45 & 0.714408 & 0.75684 \\
\hline 7 & 67.5 & 0.772752 & 0.844288 \\
\hline 8 & 90 & 0.831096 & 0.931736 \\
\hline 9 & 112.5 & 0.898348 & 1.056516 \\
\hline 10 & 135 & 0.9656 & 1.181296 \\
\hline 11 & 157.5 & 1.039856 & 1.37088 \\
\hline 12 & 180 & 1.114112 & 1.560328 \\
\hline 13 & 203 & 1.198976 & 1.842392 \\
\hline 14 & 226 & 1.28384 & 2.124456 \\
\hline \multicolumn{4}{|c|}{15} \\
\hline 16 & Weight & distrib & point \\
\hline 17 & 0 & $=\mid F(A N D(0<G 15, G 15<10), A V E R A G E(M 3: M 4), 0)$ & $=I F(A N D(0<G 15, G 15<10), A V E R A G E(N 3: N 4), 0)$ \\
\hline 18 & 10 & =IF(AND(9.9<G15,G15<27.5),AVERAGE(M4:M5),0) & $=\operatorname{IF}(\mathrm{AND}(9.9<\mathrm{G} 15, \mathrm{G} 15<27.5)$, AVERAGE(N4:N5),0) \\
\hline 19 & 27.5 & $=\mid F($ AND(27.4<G15,G15<45),AVERAGE(M5:M6),0) & $=|=|$ (AND $(27.4<G 15, G 15<45)$, AVERAGE(N5:N6),0) \\
\hline 20 & 45 & $=\mid F(A N D(44.9<G 15, G 15<67.5), A V E R A G E(M 6: M 7), 0)$ & $=\mid$ F(AND(44.9<G15,G15<67.5),AVERAGE(N6:N7),0) \\
\hline 21 & 67.5 & $=\mid F(A N D(67.4<G 15, G 15<90)$, AVERAGE(M7:M8),0) & $=I F(A N D(67.4<G 15, G 15<90), A V E R A G E(N 7: N 8), 0)$ \\
\hline 22 & 90 & $=I F(A N D(89.9<G 15, G 15<112.5), A V E R A G E(M 8: M 9), 0)$ & $=\mid F(A N D(89.9<G 15, G 15<112.5), A V E R A G E(N 8: N 9), 0)$ \\
\hline 23 & 112.5 & $=\mid \mathrm{IF}(\mathrm{AND}(112.4<G 15, \mathrm{G} 15<135), \mathrm{AVERAGE}(\mathrm{MS}: M 10), 0)$ & $=I F(A N D(112.4<G 15, G 15<135), A V E R A G E(N 9: N 10), 0)$ \\
\hline 24 & 135 & $=\mid F($ AND $(134.9<G 15, G 15<157.5)$, AVERAGE $(M 10: M 11), 0)$ & $=I F(A N D(134.9<G 15, G 15<157.5), A V E R A G E(N 10: N 11), 0)$ \\
\hline 25 & 157.5 & $=|=|$ F(AND(157.4<G15,G15<180),AVERAGE(M11:M12),0) & $=\mid F(A N D(157.4<G 15, G 15<180), A V E R A G E(N 11: N 12), 0)$ \\
\hline 26 & 180 & $=\operatorname{IF}(\mathrm{AND}(179.9<\mathrm{G} 15, \mathrm{G} 15<203), \mathrm{AVERAGE}(\mathrm{M} 12: \mathrm{M} 13), 0)$ & $=\mid F($ AND(179.9<G15,G15<203),AVERAGE(N12:N13),0) \\
\hline 27 & 203 & $=$ =IF(AND(202.9<G15,G15<226),AVERAGE(M13:M14),0) & $=\mid \mathrm{F}(\mathrm{AND}(202.9<\mathrm{G} 15, \mathrm{G} 15<226), \mathrm{AVERAGE}(\mathrm{N} 13: \mathrm{N} 14), 0)$ \\
\hline \multicolumn{4}{|c|}{\begin{tabular}{l|l}
28 & 226 \\
\end{tabular}} \\
\hline \multicolumn{4}{|l|}{29} \\
\hline \multicolumn{4}{|l|}{30} \\
\hline \multirow{2}{*}{\multicolumn{4}{|c|}{$\begin{array}{ll}31 \\
32\end{array}$}} \\
\hline & & & \\
\hline \multicolumn{4}{|l|}{33} \\
\hline \multicolumn{4}{|l|}{34} \\
\hline \multicolumn{4}{|l|}{35} \\
\hline \multicolumn{4}{|l|}{36} \\
\hline \multicolumn{4}{|l|}{37} \\
\hline 38 & & & \\
\hline 39 & & & \\
\hline
\end{tabular}


CHPRC-00922, REV. 0

\section{Appendix C-1}

Nonautomated Worksheet for 4 by 7 by 3-Foot Box 
CHPRC-00922, REV. 0

C-1-ii 


\section{APPENDIX C-1}

\section{Nonautomated Worksheet for 4 x 7 x 3-Foot Box Dose Rate to Curie Content}

Instrument

\begin{tabular}{|c|c|c|}
\hline \multicolumn{3}{|c|}{ Surface Dose Rates } \\
\hline & \multicolumn{2}{|c|}{ Dose rate (mR/hr) } \\
\hline Side 1 & 205 & \\
\hline Side 2 & 210 & \\
\hline Side 3 & 205 & \\
\hline Side 4 & 200 & \\
\hline Top & 185 & \\
\hline Bottom & 195 & \\
\hline Average & 200 & \\
\hline \multirow{2}{*}{\multicolumn{2}{|c|}{$\begin{array}{l}\text { Backround Radiation: } \\
\text { Average - Backround }\end{array}$}} & 0.5 \\
\hline & & 199.5 \\
\hline \multicolumn{2}{|c|}{ Maximum Dose Rate: } & 210 \\
\hline \multicolumn{2}{|c|}{ Maximum/Average: } & 1.05 \\
\hline \multicolumn{2}{|c|}{ Dose Rate to Activity Curve: } & Distributed \\
\hline
\end{tabular}

Calib or Cert

\begin{tabular}{|l|r|}
\hline \multicolumn{2}{|c|}{ Container Information } \\
\hline Wet Weight $\geq 77.5$ and <1085 to 1 decimal place. \\
Container Number \\
Volume $\left(\mathrm{ft}^{3}\right)$
\end{tabular}

\begin{tabular}{|c|r|r|}
\hline \multicolumn{3}{|c|}{ Ci Factor for Box Wt. } \\
\hline & \multicolumn{1}{|c|}{ Cs-137 Curies per R/hr } \\
Weight (kg) & Point & Distributed \\
\hline 99.9 & 1.78 & 2.20 \\
\hline
\end{tabular}

\begin{tabular}{|c|c|c|c|c|}
\hline \multicolumn{5}{|c|}{ Isotope Concentration } \\
\hline \multirow[b]{2}{*}{ Isotope } & \multicolumn{2}{|c|}{ Curies (Ci) } & \multicolumn{2}{|c|}{ Distribution (\%) } \\
\hline & Point & Distributed & Point & Distributed \\
\hline Cs-137 & 0.355117 & 0.439750 & $28.82 \%$ & $28.82 \%$ \\
\hline Ba-137m & 0.335692 & 0.415696 & $27.24 \%$ & $27.24 \%$ \\
\hline Sr-90 & 0.270244 & 0.334650 & $21.93 \%$ & $21.93 \%$ \\
\hline$Y-90$ & 0.270244 & 0.334650 & $21.93 \%$ & $21.93 \%$ \\
\hline Eu-154 & 0.000806 & 0.000998 & $0.07 \%$ & $0.07 \%$ \\
\hline Tc-99 & 0.000121 & 0.000150 & $0.01 \%$ & $0.01 \%$ \\
\hline Pd-107 & 0.000001 & 0.000001 & $0.00 \%$ & $0.00 \%$ \\
\hline Cs-134 & 0.000001 & 0.000001 & $0.00 \%$ & $0.00 \%$ \\
\hline Pm-147 & 0.000088 & 0.000109 & $0.01 \%$ & $0.01 \%$ \\
\hline Eu-155 & 0.000047 & 0.000058 & $0.00 \%$ & $0.00 \%$ \\
\hline Sum & 1.232223 & 1.525894 & $100.00 \%$ & $100.00 \%$ \\
\hline
\end{tabular}


CHPRC-00922, REV. 0

C-1-2 
CHPRC-00922, REV. 0

\section{Appendix C-2}

Automated Worksheet for 4 by 7 by 3-Foot Box 
CHPRC-00922, REV. 0

C-2-ii 


\section{APPENDIX C-2}

\section{Automated Worksheet for 4 x 7 x 3-Foot Box with 1/2-Inch Rubber Lining Dose Rate to Curie Content}

Instrument

\begin{tabular}{|l|l|}
\hline \multicolumn{2}{|c|}{ Surface Dose Rates } \\
\hline & Dose rate (mR/hr) \\
\hline Side 1 & \\
\hline Side 2 & \\
\hline Side 3 & \\
\hline Side 4 & \\
\hline Top & \\
\hline Bottom & \\
\hline Average & \\
\hline \multicolumn{2}{|c|}{ Backround Radiation: } \\
Average - Backround: \\
Maximum Dose Rate: \\
Maximum/Average: \\
Dose Rate to Activity Curve: \\
\hline
\end{tabular}

Calib or Cert

\begin{tabular}{|l|l|}
\hline \multicolumn{2}{|c|}{ Container Information } \\
\hline Net Weight $\geq 77.5$ and $<1085$ to 1 decimal place. \\
Container Number \\
Volume $\left(\mathrm{ft}^{3}\right)$ \\
Volume $\left(\mathrm{m}^{3}\right)$ \\
Empty Weight $(\mathrm{kg})$ & \\
\cline { 2 - 2 } Gross Weight $(\mathrm{kg})$ & \\
\cline { 2 - 2 } Net Weight $(\mathrm{kg})$ & \\
\cline { 2 - 2 }
\end{tabular}

Prepared by:

Print Name

Signature

Date:

Attachments: 
CHPRC-00922, REV. 0 


\section{Appendix C-3}

Calculations Supporting the Automated Worksheet for 4 by 7 by 3-Foot Box 
CHPRC-00922, REV. 0

C-3-ii 


\begin{tabular}{|c|c|c|c|c|c|c|c|c|c|}
\hline & $\bar{A}$ & $B$ & $\mathrm{C}$ & $\mathrm{D}$ & $E$ & $F$ & $\mathbf{G}$ & $\mathrm{H}$ & $\mathrm{I}$ \\
\hline 1 & & & APPENDIX C-3 & & & & & & \\
\hline 2 & & & Calculations & & & & & & \\
\hline 3 & \multicolumn{8}{|c|}{ Spreadsheet for $4^{\prime} \times 7^{\prime} \times 3^{\prime}$ Box } & \\
\hline 4 & \multicolumn{9}{|c|}{ Dose Rate to Curie Content } \\
\hline 5 & & & & & & & & & \\
\hline 6 & Instrument & & & & Calib or Cert & & & & \\
\hline 7 & & & & & & & & & \\
\hline 8 & & & & & & & & & \\
\hline 9 & \multicolumn{3}{|c|}{ Surface Dose Rates } & & \multicolumn{3}{|c|}{ Container Information } & & \\
\hline 10 & & Dose rate $(\mathrm{mR} / \mathrm{hr})$ & & & \multicolumn{3}{|c|}{ Net Welght 277.5 and $<1085$ to 1 dedmol place. } & & \\
\hline 11 & Side 1 & 205 & & & \multicolumn{2}{|l|}{ Container Number } & & & \\
\hline 12 & Side 2 & 210 & & & Volume $\left(\mathrm{ft}^{3}\right)$ & & 84 & & \\
\hline 13 & Side 3 & 205 & & & \multicolumn{2}{|l|}{ Volume $\left(\mathrm{m}^{3}\right)$} & $=\mathrm{G12} * 0.028316847$ & & \\
\hline 14 & Side 4 & 200 & & & \multicolumn{2}{|l|}{ Empty Weight (kg) } & 50 & & \\
\hline 15 & Top & 185 & & & \multicolumn{2}{|l|}{ Gross Weight (kg) } & 149.9 & & \\
\hline 16 & Bottom & 195 & Distributed & & \multicolumn{2}{|l|}{ Net Weight (kg) } & $=\mathrm{G} 15-\mathrm{G} 14$ & & \\
\hline 17 & Average & $=S U M(B 11: B 16) / 6$ & Point & & & & & & \\
\hline 18 & & Backround Radiation: & 0.5 & & & & & & \\
\hline 19 & & Average - Backround: & $=B 17-\mathrm{C} 18$ & & \multicolumn{3}{|c|}{ Ci Factor for Box Wt. } & & \\
\hline 20 & & Maximum Dose Rate: & $=\operatorname{MAX}(B 11: B 16)$ & & & \multicolumn{2}{|c|}{ Curies per $\mathrm{R} / \mathrm{hr}$} & & \\
\hline 21 & & Maximum/Average: & $=C 20 / B 17$ & & Weight (kg) & Point & Distributed & & \\
\hline 22 & Dose Rate to Activity Curve: & & $=I F(C 21<2.5, C 16, C 17)$ & & $=616$ & $=\operatorname{Max}(019: 032)$ & $=$ MAX(N19:N32) & & \\
\hline \multicolumn{10}{|c|}{23} \\
\hline \multicolumn{10}{|l|}{24} \\
\hline \multicolumn{10}{|l|}{25} \\
\hline 26 & \multicolumn{7}{|c|}{ Isotope Concentration } & & \\
\hline 27 & & \multicolumn{2}{|c|}{ Curies $(\mathrm{Ci})$} & \multicolumn{2}{|c|}{ Distribution (\%) } & & & & \\
\hline 28 & Isotope & Point & Distributed & Point & Distributed & & & & \\
\hline 29 & Cs-137 & $=C 19 / 1000^{*}$ SUM(019:032) & $=$ C19/1000*SUM(N19:N32) & $=\mathrm{B} 29 / \mathrm{B} 40$ & $=\mathrm{C} 29 / \mathrm{C} 40$ & & & & \\
\hline 30 & $\mathrm{Ba}-137 \mathrm{~m}$ & $=0.9453 * \mathrm{~B} 29$ & $=0.9453^{*} C 29$ & $=B 30 / B 40$ & $=C 30 / C 40$ & & & & \\
\hline 31 & $\mathrm{Sr}-90$ & $=0.761{ }^{*} \mathrm{~B} 29$ & $=0.761^{*} \mathrm{C} 29$ & $=\mathrm{B3} 1 / \mathrm{B} 40$ & $=C 31 / \mathrm{C} 40$ & & & & \\
\hline 32 & $Y-90$ & $=831$ & $=0.761^{*} \mathrm{C} 29$ & $=\mathrm{B} 32 / \mathrm{B} 40$ & $=C 32 / C 40$ & & & & \\
\hline 33 & Eu-154 & $=0.00227 * B 29$ & $=0.00227 * C 29$ & $=\mathrm{B33} / \mathrm{B} 40$ & $=\mathrm{C33} / \mathrm{CAO}$ & & & & \\
\hline 34 & Tc-99 & $=829^{\circ} 0.00034$ & $=C 29 * 0.00034$ & $=\mathrm{B} 34 / \mathrm{B} 40$ & $=C 34 / C 40$ & & & & \\
\hline 35 & Pd-107 & $=829^{*} 0.00000178$ & $=C 29^{*} 0.00000178$ & $=\mathrm{B3} 35 / \mathrm{BAO}$ & $=C 35 / C 40$ & & & & \\
\hline 36 & Cs-134 & $=829 * 0.000002$ & $=029 * 0.000002$ & $=\mathrm{B3} 36 / \mathrm{B} 40$ & $=C 36 / C 40$ & & & & \\
\hline 37 & $\mathrm{Pm}-147$ & $=829 * 0.000247$ & $=029 * 0.000247$ & $=\mathrm{B3} 3 / \mathrm{B} 40$ & $=C 37 / C 40$ & & & & \\
\hline 38 & Eu-155 & $=829 * 0.000133$ & $=C 29 * 0.000133$ & $=\mathrm{B3} 8 / \mathrm{B} 40$ & $=C 38 / C 40$ & & & & \\
\hline 39 & & & & & & & & & \\
\hline 40 & Sum & $=$ SUM(B29:B34) & =SUM(C29:C34) & =SUM(D29:D34) & =SUM(E29:E34) & & & & \\
\hline
\end{tabular}




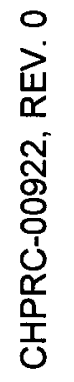

ญे 
CHPRC-00922, REV. 0

\section{Appendix D}

\section{Dose-to-Curie Content Curves}


CHPRC-00922, REV. 0

D-ii 


\section{Appendix D Dose to Curie Curves}
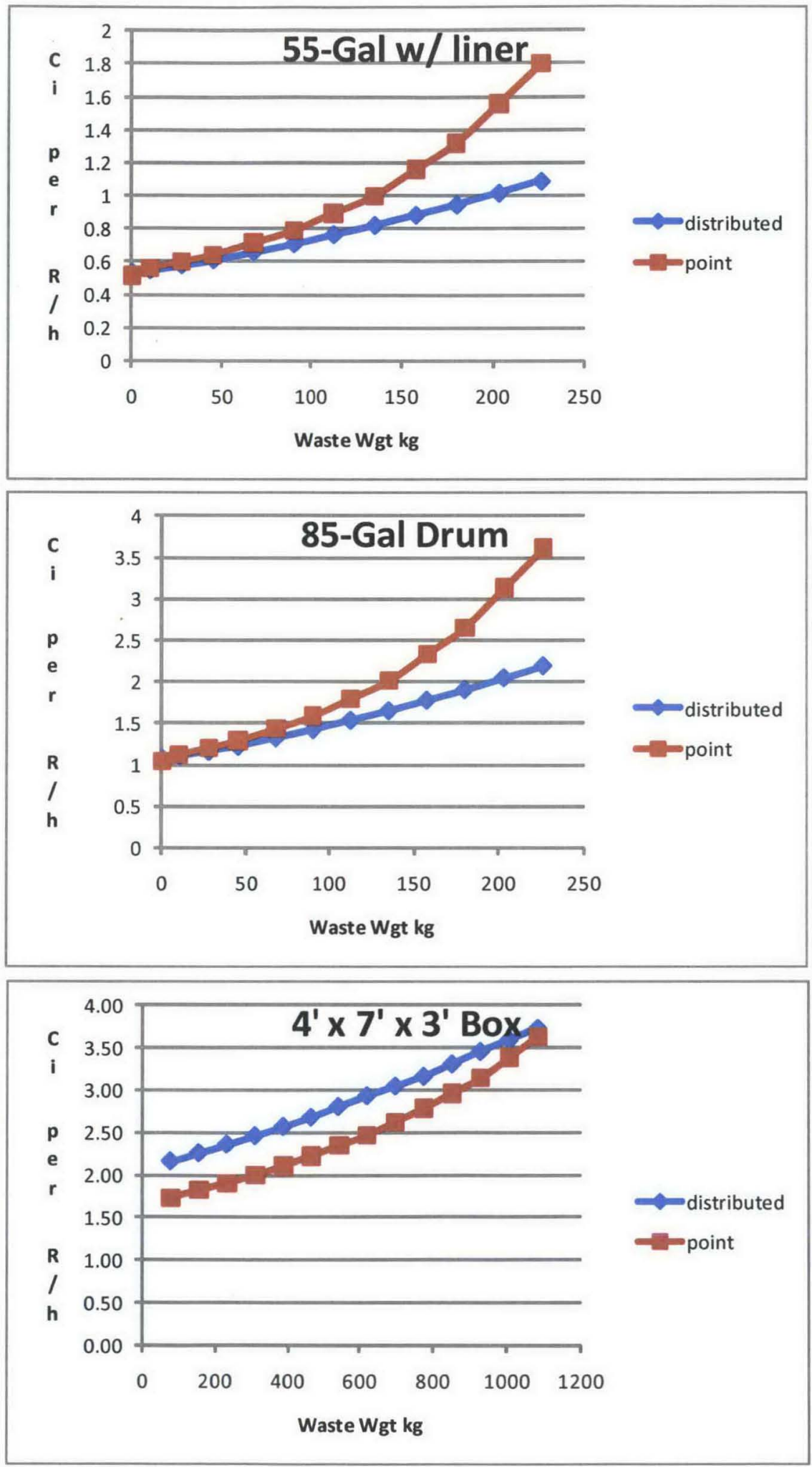

D-1 
CHPRC-00922, REV. 0 